(C) Shepitko K.V.

UDC: 617.55-002:616.34:[615.361+618.36]

DOI https://doi.org/10.31718/mep.2019.23.5-6.08

\title{
CHANGES IN HEMOMICROCIRCULATORY BED OF RAT ILEUM MUCOSA IN TRANSPLANTATION OF CRYOPRESERVED PLACENTA AGAINST THE BACKGROUND OF ACUTE ASEPTIC INFLAMMATION OF PERITONEUM*
}

Shepitko K.V.

Ukrainian Medical Stomatological Academy, Poltava

The work is a fragment of the research project "Experimental and morphological study of the cryopreserved placenta graft and other exogenous factors effect on the morpho-functional status of certain internal organs", state registration No. $0113 \mathrm{U} 006185$.

Гемомікроциркуляторне русло (ГМЦР) в сучасному розумінні являє собою складно організовану систему, що забезпечує впорядкований рух крові, тканинних рідин, всмоктування і виділення біохімічних субстратів, метаболітів, біологічно активних речовин. Серед взаємопов'язаних і взаємообумовлених процесів у системі ГМЦР основна роль належить закономірностям циркуляції крові в судинах. Останнє десятиліття ознаменувалось зовсім новим підходом при вирішенні проблем пов'язаних з порушеннями кровонаповнення. Застосування тканинної трансплантації, зокрема препаратів кріоконсервованої плаценти, як корегуючого метода, являється досить ефективним. Останнє явилось підставою для проведення комплексного вивчення реакції ГМЦР слизової оболонки клубової кішки на трансплантацію кріоконсервованої плаценти. Метою роботи було вивчення динаміки показників гемомікроциркуляторного русла слизової оболонки клубової кишки при одноразовому введенні кріоконсервованої плаценти та при введені кріоконсервованої плаценти на тлі гострого асептичного експериментального запалення очеревини у щурів. Об'єкт і методи дослідження. Об'єктом експериментального дослідження була стінка клубової кишки, вилучена від 140 статевозрілих щурів-самців лінії "Вістар". Тварини були розділені на чотири групи. Тварин виводили з експерименту на (1, 2, 3, 5, 7, 10, 14, 21, 30 доби). Проводили вимірювання внутрішнього діаметру судин ГМЦР в слизовій оболонці. Математична обробка проводили за критерію Ст'юдента (t). Достовірними вважались розбіжності при p<0,05. Трансплантація кріоконсервованої плаценти викликає реакцію всіх ланок гемомікроциркуляторного русла за рахунок збільшення середнього їх діаметра з максимальними показниками на 5 добу. Моделювання гострого асептичного запалення очеревини спочатку призводило до зменшення в діаметрі артеріол на 5\% і капілярів на 2.3\%, на 2-3 доби, а потім збільшення їх діаметрів, на 14 добу дослідження. Венулярна ланка протягом експерименту збільшилася в діаметрі, на 14 добу дослідження. При трансплантації кріоконсервованої плаценти на тлі гострого асептичного запалення очеревини артеріоли на 4\% і капіляри на 2\% спочатку зменшуються в діаметрі на 2 добу, а потім збільшилися в діаметрі на 3-10 доби дослідження. Венулярна ланка протягом експерименту суттєво збільшувалась в діаметрі, на 14 добу дослідження. При введенні кріоконсервованої плаценти на тлі гострого асептичного запалення очеревини термін реалізації запалення скоротився на 4-5 діб.

Ключові слова: клубова кишка, слизова, гемомікроциркуляторне русло, кріоконсервована плацента, асептичне запалення.

Hemomicrocirculatory bed (HMCB) in the modern sense is a complex organized system that provides ordered motion of blood, tissue fluids, absorption and excretion of biochemical substrates, metabolites, biologically active substances. Among the interrelated and interdependent processes in the system of HMCB, the main role belongs to the patterns of blood circulation in the vessels. The last decade has been marked by a completely new approach to solving problems associated with impaired blood filling. The use of tissue transplantation, in particular cryopreserved placenta grafts, as a corrective method, is quite effective. The latter was the basis for a comprehensive study of the ileal mucosa HMCB response to the cryopreserved placenta transplantation [11]. The aim of this study was to investigate the dynamics of the ileum mucosa hemo-microcirculatory bed parameters with a single administration of cryopreserved placenta and with the cryopreserved placenta administration against the background of acute aseptic experimental peritoneum inflammation in rats. Object and methods of the study. The object of the experimental study was the ileum wall sampled from 140 mature Wistar male rats. The animals were divided into four groups. Animals were euthanized on the 1st, 2nd, 3rd, 5th, 7th, 10th, 14th, 21st, 30th days. Measurements of the HMCB vessels internal diameter in the ileac mucosa were performed. The mathematical processing was performed by means of Student's t test ( $t)$. Differences at $p<0.05$ were considered reliable. Transplantation of cryopreserved placenta causes the reaction of all links of the hemomicrocirculatory bed by increasing their average diameter with maximum values for 5 days. Simulation of acute aseptic inflammation of the peritoneum initially led to a decrease in the diameter of arterioles by 5\% and capillaries by 2.3\%, by 2-3 days, and then by an increase in their diameters, by the 14th day of the study. During the experiment, the venular unit increased in diameter by the 14th day of the study. When transplanting cryopreserved placenta against acute aseptic inflammation of the peritoneum of the arterioles by $4 \%$ and capillaries by $2 \%$, they first decrease in diameter by 2 days, and then increase in diameter by 3-10 days of the study. During the experiment, the venular unit significantly increased in diameter by the 14th day of the study. With the introduction of cryopreserved placenta on the background of acute aseptic inflammation of the peritoneum, the realization of inflammation decreased by 4-5 days.

Keywords: ileum, mucosa, hemomicrocirculatory bed, cryopreserved placenta, aseptic inflammation.

\footnotetext{
* To cite this english version: Shepitko K.V. Changes in hemomicrocirculatory bed of rat ileum mucosa in transplantation of cryopreserved placenta against the background of acute aseptic inflammation of peritoneum. // The Medical and ecological problems. 2019. - Vol 23, № 5-6. - P. 45-49.
} 
Hemomicrocirculatory bed (HMCB) in the modern sense is a complex organized system that provides ordered motion of blood, tissue fluids, absorption and excretion of biochemical substrates, metabolites, biologically active substances. Among the interrelated and interdependent processes in the system of HMCB, the main role belongs to the patterns of blood circulation in vessels with diameters from 2 to $200 \mu \mathrm{m}$, the blood cells behavior, transcapillary exchange and ultrastructural features of microvessels [1, 2, 5, 7, 9].

The last decade has been marked by a completely new approach to solving problems associated with impaired blood filling and blood outflow from the damaged organ with the destructive changes caused by the inflammatory process in the body. The use of tissue transplantation, in particular cryopreserved placenta grafts, as a corrective method, is quite effective $[3,4,8,10]$.

The latter was the basis for a comprehensive study of the ileal mucosa HMCB response to the cryopreserved placenta transplantation [11].

The aim of this study was to investigate the dynamics of the ileum mucosa hemo-microcirculatory bed parameters with a single administration of cryopreserved placenta and with the cryopreserved placenta administration against the background of acute aseptic experimental peritoneum inflammation in rats.

\section{Materials and methods}

The object of the experimental study was the ileum wall sampled from 140 mature Wistar male rats. The experiment was carried out in compliance with the "Rules for the Use of Laboratory Experimental Animals" (2006, annex 4) and the Declaration of Helsinki "The Universal Declaration on Animal Welfare" (UDAW).

Animals were divided into four groups: Group I - intact animals, 5 specimens; Group II - 45 animals that were singly administered cryopreserved placenta subcutaneously; Group III - 45 animals, in whom we modeled acute experimental inflammation of the peritoneum; Group IV -
45 animals, which were singly administered cryopreserved placenta subcutaneously against the background of simulated experimental acute peritoneal inflammation.

Animals were euthanized by an overdose of thiopental anesthesia in compliance with the established timeframes (on the 1st, 2nd, 3rd, 5th, 7th, 10th, 14th, 21st, 30 th days). Fragments of the ileum were embedded into paraffin and epoxy, according to conventional methods, and histological sections were made, which were stained: with hematoxylin-eosin according to Van Gizon, Hart (paraffin sections), polychrome stain, methylene blue.

Measurements of the inside diameter of HMCB vessels in the mucosa were performed. The microscope with a digital photomicrographic attachment produced by Biorex 3 company (serial number 5604). Mathematical processing of the material was performed using standard methods of variational statistics: calculation of mean values $(M)$, mean error $(m)$, Student's $t$ test $(t)$. Differences at $p<0.05$ were considered reliable $[9,10]$.

\section{Results and discussion}

Studying the morphometric indices of the HMCB resistive link of the iliac mucosa with a single cryopreserved placenta administration (group II) during the experiment between the study terms changed as represented in Fig. 1. Thus, on the 2 nd day, diameters of arterioles increased significantly as compared to the 1 st day $(p<0.05)$. On the 3rd5 th days, this index increased, but we did not find a significant difference between these terms. On the 7th day, the index decreased slightly, but when comparing it to the previous term, no significant difference was found between them. On the 10th day, the mean diameter of the arterioles had reliably decreased from the previous term. On the 10th-30th days, this index decreased, but the reliability of the difference was not significant.

Comparing the mean diameter of group II arterioles with a similar index of the intact group, we found an increase in the index value, but the difference was only significant during 2-7 days.

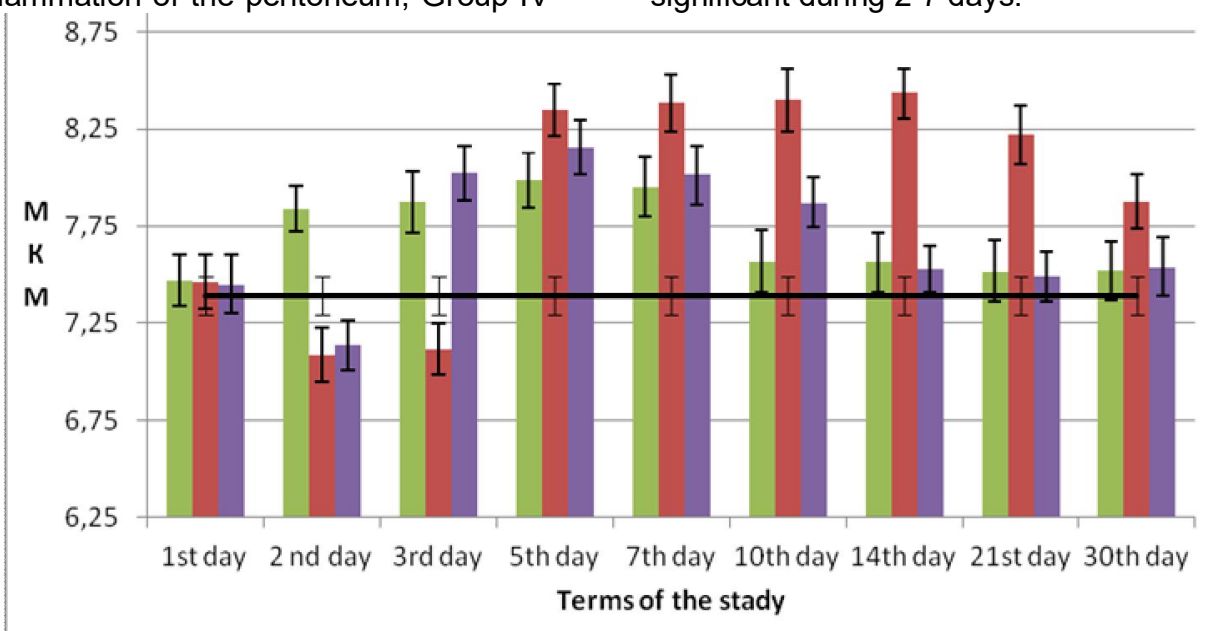

— Dlacenta inflammation - Intact

Fig. 1. Comparative characteristics of the mean arterioles diameter of the ileac mucous membrane.

Analyzing the arterioles mean diameter index in the group of animals with induced aseptic inflammation of the peritoneum (group III), we found the following changes between the terms of the study. On the 2nd day, we found a significant decrease in this index value compared to the 1 st day $(p<0.05)$. On the 3rd day, this index value increased slightly, the reliability of the difference when compared to the 2nd day was not significant, and when compared to the 1st day, it was significant at $p<0.05$. Further analysis showed a sharp increase in the index value on the 5th day, the difference reliability was significant. During the 5th-14th days, the index value continued to grow, but the difference reliability between the four terms was not significant ( $p>0.05)$. On the 21 st day, we 
established a decrease of this parameter, the difference between the 14th and the 21st days was not significant. On the 30th day, the index value decreased significantly compared to the 21st day.

Analysis of the arterioles mean diameter when comparing the group of animals that were induced acute aseptic inflammation to the group of intact animals, showed a decrease in this parameter in the animal group III. If on the first day the indices were within the intact group values, we found its significant decrease on the 2 nd and the 3rd days $(p<0.05)$. Within the 5th-21st days, the mean diameter of arterioles was significantly higher in group III when compared to a similar index of the intact group with the highest value on the 14th day. On the 30th day, a significant difference was detected in this parameter between group III and the intact group of animals.

Morphometric analysis of the arterioles mean diameter index in the group of animals that underwent the cryopreserved placenta transplantation against the background of acute aseptic inflammation of the peritoneum (group IV) showed that during the experiment it varied between the study terms (Fig. 1). On the 2nd day, we found a significant decrease in this index value compared to the 1 st day $(p<0.05)$. On the 3rd day, it increased significantly compared to the previous term.

During the 3rd-7th days this index growth was observed, but the difference between these values was not significant. On the 10th day there was a tendency to decrease this index in comparison with the previous term. On the 14th day a significant decrease in the mean diameter of the arterioles compared to the 10th day was established. On the 21st-30th days the value of this index was within the previous term limits (at $p>0.05$ ).

Analysis of the arterioles mean diameter values between the intact and group IV animals showed that on the 2nd day a significant decrease of this index was found, and on 3rd-10th days its reliable increase was detected, with a maximum value on the 5th day in group IV. On the 7th-10th day, the index value decreased slightly, but the difference between the groups was reliable $(p<0.05)$. When comparing the 14th day's values, we found a significant decrease in this parameter. On the 14th-30th days, the mean arterioles diameter was not significantly different from that of the intact group.

Thus, the resistive link of the ileac mucosa HMCB during transplantation of cryopreserved placenta was characterized by a gradual increase in the mean diameters with the maximum value on the 5th day and their restoration on the 10th day. In the modeling of acute aseptic peritoneal inflammation there was a sharp decrease in diameters on the 2 nd-3rd days with a subsequent increase within the 5th-14th days and incomplete recovery on the 30th day. The cryopreserved placenta administration, against the background of acute aseptic peritoneal inflammation, initially showed a sharp decrease in the arterioles diameter on the 2nd day with a subsequent growth on the 3rd-10th days and complete recovery on the 14th day.

Analysis of the ileum mucosa HMCB metabolic link's metric parameters with a single administration of cryopreserved placenta (group II) did not change uniformly during the experiment. The changes are presented in Fig. 2. It was found that on the 2nd day the capillary diameters increased significantly compared to the 1 st day $(p<0.05)$. During the 3rd-5th days this index value increased, but we did not find a significant difference between these terms. On the 7th day the index decreased slightly, compared to the previous term, a reliable difference between the terms was not detected ( $p>0.05$ ). On the 10th day, the mean capillary diameter significantly decreased compared to the previous term $(p<0.05)$. Within the 10th-30th days this index value decreased, but the reliability of the difference was not revealed between them.

Comparing the mean diameter of capillaries in group II to the similar index of the intact group, we found an increase in this index value, but the difference was significant only within the 2 nd-7th days (Fig. 2).

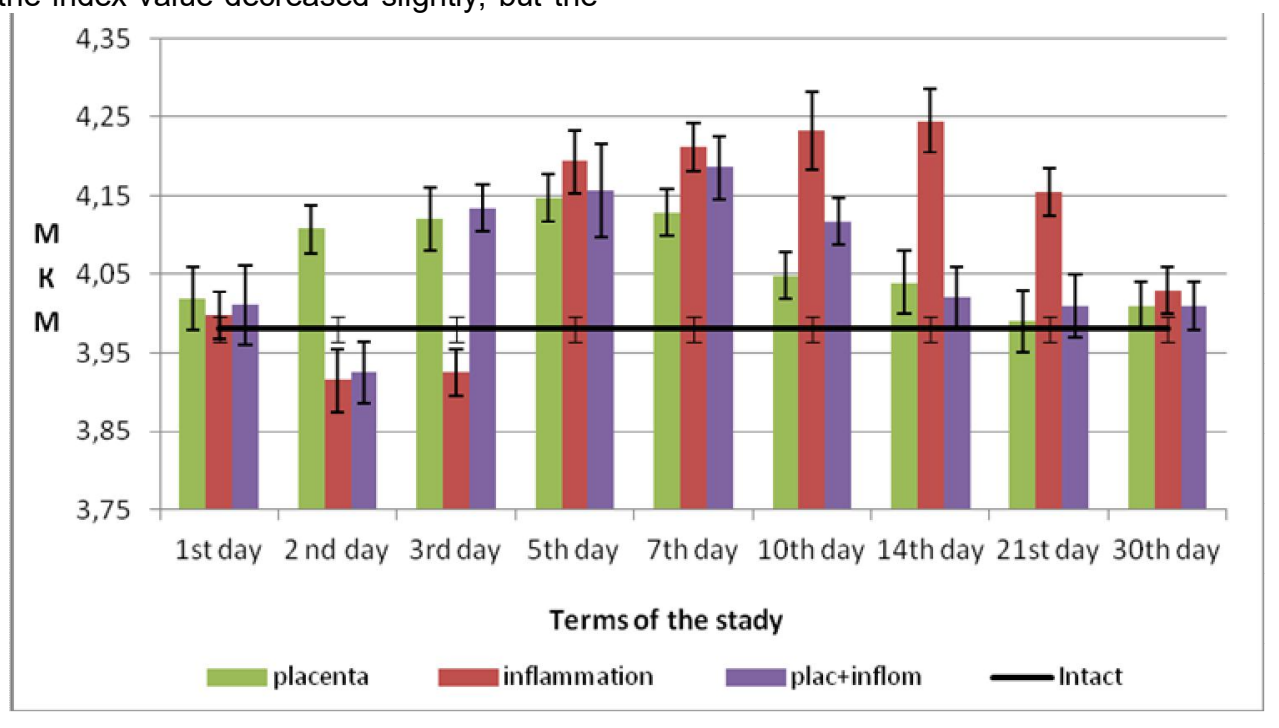

Fig. 2. Comparative characteristics of the ileum mucosa capillaries mean diameter.

Studying the index of the capillaries mean diameter in the group of animals with the induced aseptic inflammation of the peritoneum (group III), we found changes between the terms of the study. On the 2nd day, we found a significant decrease in this index value compared to the 1 st day $(p<0.05)$. On the 3rd day, this index value increased slightly, the difference reliability was not found when compared to the 2 nd day, and when compared to the 1 st day it was significant at $p<0.05$.

Further analysis showed a sharp increase in this index on the 5th day, the difference reliability was plausible. Within 5-14 days, the index value continued to increase, but the difference reliability between the four terms was revealed. On the 21 st day we observed a de- 
crease of this parameter, the difference between the 14th and the 21st days was significant. On the 30th day the index value decreased further and compared to the 21st day a reliable difference was established between them.

Analysis of the capillaries mean diameter when comparing the intact group and the animal group III showed that we found a significant decrease in the parameter on the 2 nd and the 3rd days (at $p<0.05$ ). Within 5-21 days, the mean capillary diameter was reliably larger in group III when compared to a similar intact group index with the highest value on the 14th day. On the 21st day, it decreased but had not yet equaled to that of the intact animals group and was reliably large. On the 30th day, no significant difference was found between group III and the intact animals group.

Statistical analysis of the mean capillary diameter in the group of animals that had been transplanted cryopreserved placenta against the background of acute aseptic inflammation of the peritoneum showed that during the experiment there were changes in its parameters (Fig. 2). On the 2nd day, we found a significant decrease in this value compared to the 1 st day $(p<0.05)$. On the 3rd day, it increased significantly compared to the previous term. Within 3-7 days an increase of this indicator was noted, but reliability of the difference between values was not significant. On the 10th day there was no significant decrease of this index in comparison with the previous term. On the 14th day a significant decrease of the mean capillary diameter was established. On the 21st-30th days the value of this index was within the previous term (at $p>$ 0.05).

Analysis of the mean capillary diameter indices between group IV and the intact animals group showed that on the 2 nd day a significant decrease of the index value was found, and on the 3rd-10th day its significant increase was observed, with a maximum value on the 7th day in group IV. On the 14th-30th days, the mean capil- lary diameter was not significantly different from the intact group of animals.

Thus, the exchange link of the ileum mucosa HMCB responded differently in different types of study. Thus, during transplantation of cryopreserved placenta, a gradual increase of this index was established with the maximum value on the 5th day and the recovery on the 10th day. In the modeling of acute aseptic inflammation of the peritoneum there was a sharp decrease in the diameters on the 2nd-3rd days with a subsequent increase during the 5th14 th days and the recovery on the 30th day. Administration of cryopreserved placenta against the background of acute aseptic inflammation of the peritoneum reveals that the mean diameter of the exchange HMCB link first decreased on the 2nd day, and then increased with the maximum value of this index on the 7th-10th days.

In the statistical analysis of the mean diameter in the capacitive HMCB link of the ileum mucous membrane, we found that it varied dynamically, but not equally. The results are presented in Fig. 3.

In animal group II, when comparing the indices between the study terms, there was an increase of this index on the 2nd and 3rd days, the difference between the 1 st and 2 nd days of the study was significant (at $p$ $<0.05$ ). On the 5 th day, the value of this index was maximum, but when compared to the 3rd day, there were no significant changes between the study periods. On the 7 th day there was a decrease of this index value, but the difference with the previous term was also not revealed. The period from the 10th to the 14th days is characterized by a decrease in the index. If the comparison between these terms is not significant, then with the previous term (the 7th day) the difference is reliable. This index was still decreasing on the 21st-30th days, but the difference with the previous term was also not significant. Comparing the same group to the intact animals group, we found a significant difference only for the indices on the 2 nd-7th days of the study.

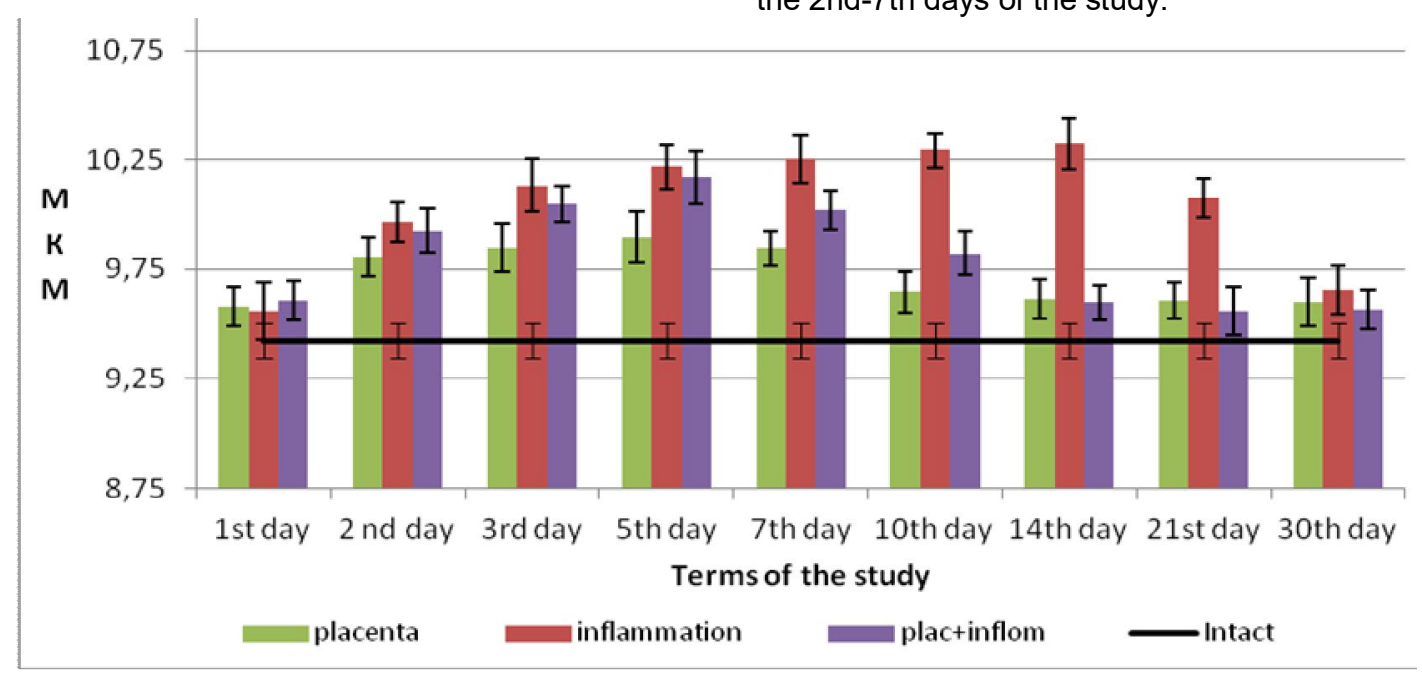

Fig. 3. Comparative characteristics of the mean venules diameter in the ileum mucous membrane.

Studying the index value in animal group III, which was induced acute aseptic inflammation of the peritoneum, we found the following changes between the study terms. On the 2nd day, we found a significant increase compared to the 1 st day $(p<0.05)$. On the period of the 3 rd-14th days there was a further increase in the mean diameter of venules, but no difference was found be- tween these terms. On the 21st-30th days there was a significant decrease in diameters, both compared to the previous term and to each other.

When comparing the intact and the animal group III, we found that a significant difference between these indices was detected within the 2nd-21st days, with the 
maximum value on the 14th day of study. Indices on the 1 st and the 30th days were within the intact group.

Metric analysis of the indices in animal group IV, which, was administered cryopreserved placenta against the background of acute aseptic inflammation of the peritoneum, found that the mean venules diameter on the second day increased significantly when compared to the index value on the 1st day and its further increase up to the 7 th day where it reached its maximum value. The reliability of the difference between the 2nd and the 10th observation terms was not significant. Within the 10th30 th days this index value decreased. The difference reliability was significant between the 10th and 14th days.

Comparison of the mean venules diameter indices between the intact animals and group IV, we found a reliable increase in the index within the 2 nd-10th days of the study, the difference reliability was $(p<0.05)$, at all the other terms the difference reliability between the groups was not revealed.

Thus, transplantation of a cryopreserved placenta causes an increase in the diameters of the capacitive HMCB link with the maximum value on the 5th day. When modeling acute aseptic inflammation of the peritoneum, there is also an increase in the diameters with the maximum value on the 14th day. Administration of cryopreserved placenta against the background of acute aseptic inflammation of the peritoneum also causes an increase in the capacitive link diameters with the maximum value on the 7 th day of the study.

\section{Conclusions}

1. Transplantation of cryopreserved placenta causes the response of all the hemomicrocirculatory bed links by increasing their mean diameter with maximum parameters, and more advanced vasculature on the 5th day.

2. Simulation of acute aseptic inflammation of the peritoneum initially led to a decrease in the arterioles diameter by $5 \%$ and that of capillaries by $2.3 \%$, on the 2 nd3 rd days, and then to their diameters increase, on the 14th day of the study. During the experiment, the venular unit increased in its diameter on the 14th day of the study.

3. In transplantation of cryopreserved placenta against acute aseptic inflammation of the peritoneum, arterioles and capillaries first decrease in their diameter (by $4 \%$ and $2 \%$ respectively) on the 2 nd day, and then increase their diameter on the 3rd-10th days of the study. During the experiment, the venular unit significantly increased in diameter on the 14th day of the study.

4. In administration of cryopreserved placenta against the background of acute aseptic inflammation of the peri- toneum, the term of inflammation onset reduced by $4-5$ days.

1. Bilash SM Morfofunktsionalna kharakterystyka strukturnykh komponentiv shlunku intaktnykh shchuriv ta pry vvedenni kriokonservovanoyi platsenty na tli hostroho eksperymentalnoho zapalennya [dysertatsiya] Ternopil: TDMU; 2013. $36 \mathrm{~s}$.

2. Gain YuM, Leonovich SI, Alekseyev SA Sindrom enteralnoy nedostatochnosti pri peritonite: teoreticheskiye i prakticheskiye aspekty, diagnostika i lecheniye. Minsk: Molodecho; 2001. 266 s.

3. http://library.univer.kharkov.ua/OpacUnicode/index.php?url $=/$ auteurs/view/246449/source: default

4. Vilkhova OV. Morfofunktsionalna kharakterystyka pidnebinnykh zaloz shchuriv $v$ normi ta pry transplantatsiyi kriokonservovanoyi platsenty [dysertatsiya] IvanoFrankivs'k: B.v; 2009. 20 s.

5. Stetsuk YeV. Stan spermatohennoho epiteliyu, hemotsyrkulyatornoho rusla simyanykiv pry aseptychnomu zapalenni i transplantatsiyi kriokonservovanoyi platsenty. Aktual. probl. suchasn. med.: Visn. Ukr. med. stomat. akad. $2005 ; 5,4(12): 90$.

6. Siplivyy VA, Grinchenko SV, Gorgol NI i dr. Patomorfologicheskiye osobennosti hemomikrotsirkulyatornogo rusla tonkogo y tolstogo kishechnika pri ostrom peritonyt. Klinichna khirurhiya. 2014; 1:61-63.

7. Skotorenko TA, Shepitko VI, Shepitko KV. Vplyv kriokonservovanoyi platsenty na morfofunktsionalnyy stan nadnyrkovykh zaloz v normi: monohrafiya. Poltava: 2018. 73.s.

8. Chernenko NV, Katayev SI, Malysheva MS. Gemomikrotsirkulyatornoye ruslo pecheni vo vzaimootnoshenii $\mathrm{s}$ putyami vyvedeniya zhelchi.. Morfologicheskiye vedomosti. 2004; 1-2: 48.

9. Shepitko VI, Yeroshenko GA, Yurchenko TM, Shepitko IV Kriokonservovana platsenta: vplyv na perebih eksperementalnoho siadadenitu. Poltava: Kopyrservys; 2013. 122s.

10. Shepitko KV. Kharakterystyka hemomikrotsyrkulyatornoho rusla slyzovoyi obolonky dvanadtsyatypaloyi kyshky pry transplantatsiyi kriokonservovanoyi platsenty na tli hostroho aseptychnoho zapalennya ocherevyny u shchuriv. Svit medytsyny ta biolohiyi. 2015; 11,2 (49): 152156.

11. Shepitko KV. Reaktsiya hemomikrotsyrkulyatornoho rusla slyzovoyi obolonky porozhnyoyi kyshky pry transplantatsiyi kriokonservovanoyi platsenty na tli hostroho aseptychnoho zapalennya ocherevyny $\mathrm{u}$ shchuriv. Visnyk problem medytsyny i biolohiyi. 2015; 2, 4 (121):225-260.

12. Shepitko KV. Kharakterystyka morfometrychnykh parametriv stinky klubovoyi kyshky pry odnorazovomu vvedenni kriokonservovanoyi platsenty ta aseptychnomu zapalenni. Svit medytsyny ta biolohiyi. 2014; 4(46): 174178.

Матеріал надійшов до редакції 16.10.2019. 